
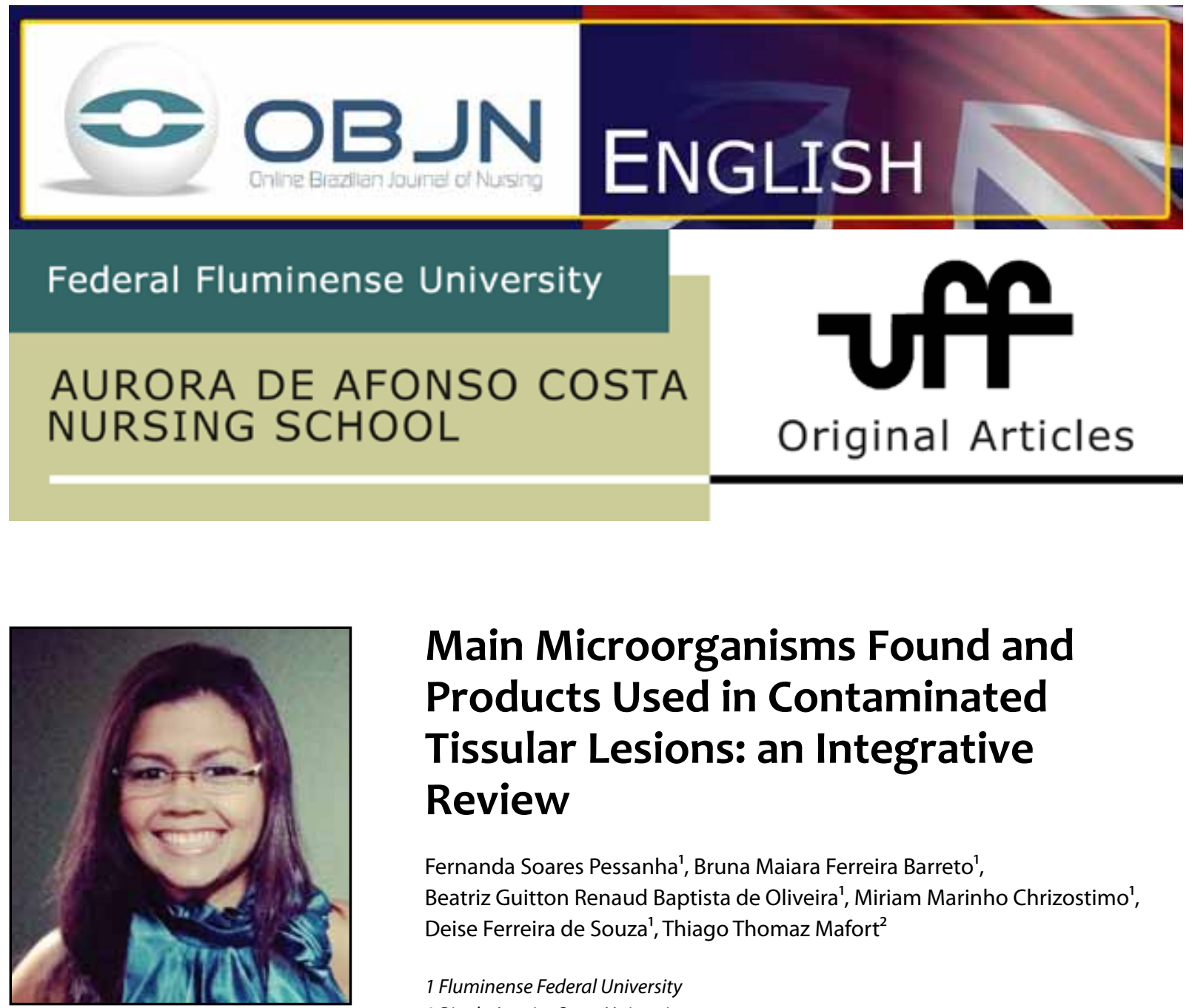

\title{
Main Microorganisms Found and Products Used in Contaminated Tissular Lesions: an Integrative Review
}

\author{
1 Fluminense Federal University \\ 2 Rio de Janeiro State University
}

Fernanda Soares Pessanha', Bruna Maiara Ferreira Barreto', Beatriz Guitton Renaud Baptista de Oliveira', Miriam Marinho Chrizostimo', Deise Ferreira de Souza', Thiago Thomaz Mafort ${ }^{2}$

\section{ABSTRACT}

Aim: To make an integrative review to examine the scientific evidences relating to the identification of microorganisms commonly isolated in contaminated tissular lesions and the main products used on them. Method: This is an integrative review originating from the search with the descriptors Leg ulcer, infection, bacteria and Nursing, in the databases LILACS, IBECS, MEDLINE, Cochrane and SciELO, including articles published between 2003 and 2013. Results: A total of 14 articles were selected, of which seven were observational and the other seven were experimental studies. Discussion: Staphylococcus aureus and Pseudomonas aeruginosa were the most prevalent microorganisms in the evaluated tissular lesions, followed by Enterobacter, Klebsiella pneumoniae and Acinetobacter. The main products used were silver alginate, silver sulfadiazine, ultraviolet light and papain, which are effective in reducing the bacterial load of infected injuries. Conclusion: The early identification of the presence of microorganisms in lesions allows the decision in terms of the appropriate propaedeutics to be performed.

Descriptors: Leg Ulcer; Infection; Bacteria; Nursing. 


\section{INTRODUCTION}

The care in terms of chronic injuries is a common activity in nursing practice. Therefore, it is important that professionals have the appropriate knowledge for the evaluation and decision making in terms of the most appropriate therapy ${ }^{(1)}$.

Chronic injuries are defined as those that take more than six weeks to heal ${ }^{(1.2)}$. Considered a serious problem world-wide, they are responsible for significant morbidity and mortality rates, as well as they cause considerable economic impact - around 25 billion dollars per year ${ }^{(2,3)}$.

One of the many factors that aggravate the tissue repair process in injuries is the presence of infection in the lesion ${ }^{(3,4)}$. This is a current issue for various reasons, such as the increased prevalence and severity of clinical and epidemiological consequences, the growing threat of prevalent microorganisms, the importance of the rational use of antibiotics and the need to improve the diagnosis and the correct treatment by means of new therapeutic options.

In this context, it is important to differentiate colonized, contaminated and infected wounds. Contamination is defined by the presence of microorganisms on the epithelial surface with no tissue invasion, physiological reaction or metabolic dependence on the host. In the colonization process, there is a relation between metabolic dependence and the host and colony formation, but without clinical expression or immune response. Infection, in turn, implies parasitism with metabolic interaction, inflammatory reaction and immune respons $\mathrm{e}^{(3)}$ - circumstances that can only be measured by means of laboratory tests.
The local indicators of an infected lesion are pain, redness, swelling, heat and purulent exudate, while the additional signs and symptoms can be healing without evolution, wound bed discoloration, friable granulation, foul odor, tunnel into the soft tissues, wound disruption, bloody exudate and serous exudate increased ${ }^{(1.3)}$. However, the mere absence of clinical signs of infection in wounds not necessarily indicates the absence of infection, since there are lesions that, even with significant amounts of microorganisms, do no present signs or symptoms ${ }^{(3)}$.

The presence of infection slows the healing process due to a prolonged inflammatory phase, reducing the synthesis of collagen, delaying epithelialization and causing constant injuries to the tissue, because bacteria compete with fibroblasts and other cells for the limited amount of oxygen, thus worsening the healing prognosis ${ }^{(1)}$.

The failure to implement the specific microbiological laboratory tests for the definition of bacterial species and their susceptibility to antimicrobial agents end up leading to the indiscriminate use of antibiotics. As a result, lesions that are only infected or colonized end up evolving to levels of infection due to the inappropriate use of antimicrobial treatments ${ }^{(5,6)}$.

Because of this, when we identify the products used in injuries and their biocidal actions in clinical practice by means of this review, it will be possible to promote the rational use of these treatments. It should be noted that the reduced number of studies on the identification of the main pathogens and products used in tissue damage limits the determination of the most appropriate treatment strategies.

The questions that guide this study are: What are the species of microorganisms 
commonly isolated in contaminated tissular lesions? What are the main products used in contaminated tissular lesions?

This study aims to analyze the scientific productions related to the identification of microorganisms commonly isolated in infected tissue lesions as well as the main products used on them.

\section{METHOD}

Integrative review conducted from an electronic bibliographical survey in all databases contained in the Virtual Health Library (VHL): Latin American and Caribbean Health Sciences (LILACS), Spanish Bibliographic Index of Health Sciences (IBECS), International Literature in Health Sciences (MEDLINE), Cochrane Library and Scientific Electronic Library Online (SciELO). The descriptors were determined from the tools Medical Subject Headings Section (MeSH), PubMed/MEDLINE, and Descriptors in Health Sciences (DeCS), of the VHL Portal: Leg Ulcer; Infection; Nursing; and Bacteria. We used the AND Boolean operator.

Inclusion criteria: all types of studies (experimental, quasi-experimental, observational and review) that addressed the microorganisms found in contaminated tissular lesions or the products used in them. Data collection was performed in any sector of the hospital scenario; in Portuguese, English and Spanish; and published between 2003 and 2013.

Exclusion criteria: reflection articles; revisions without a clear and reproducible methodology; studies containing only records of clinical trials and/or summaries of integrative reviews; studies involving non-human populations.
The research was held between September 8 and 12, 2014. The works were read by two reviewers independently, in order to ascertain whether they would meet the inclusion criteria. In times of disagreement, a third reviewer was asked to endorse the decision to include the article in the integrative review. The Kappa index was 0.95 , and it was carried out based on the degree of concordance observed (0.99) and degree of expected agreement (0.88).

The recommendations Strengthening the Reporting of Observational Studies in Epidemiology Statement (STROBE) were used as a methodological quality indicator of articles by means of an observational method ${ }^{(7)}$. The evaluation of this integrative review was divided into three categories: A - in case studies fulfill an equal to or greater value than $80 \%$ of the criteria; B - in the case of fulfillment between 80 and $50 \%$ of the criteria and C - in case there is a fulfillment that is lower than $50 \%$ of the criteria established by the STROBE ${ }^{(7)}$.

For randomized clinical trials the analysis according to the Consolidate Standards of Reporting Trials (CONSORT) was used. The same assessment mentioned above was followed in three categories: A - in case studies fulfill an equal to or greater value than $80 \%$ of the criteria; B - in the case of fulfillment between 80 and $50 \%$ of the criteria stablished and $\mathrm{C}$ - in case there is a fulfillment that is lower than $50 \%$ of the criteria established by the CONSORT $^{(8)}$.

\section{RESULTS}

The flow chart (Figure 1) details the search steps to select the articles included in the review. 
Figure 1 - Search strategy and selection of articles in the databases contained in the Virtual Health Library (VHL). Niteroi, 2014.

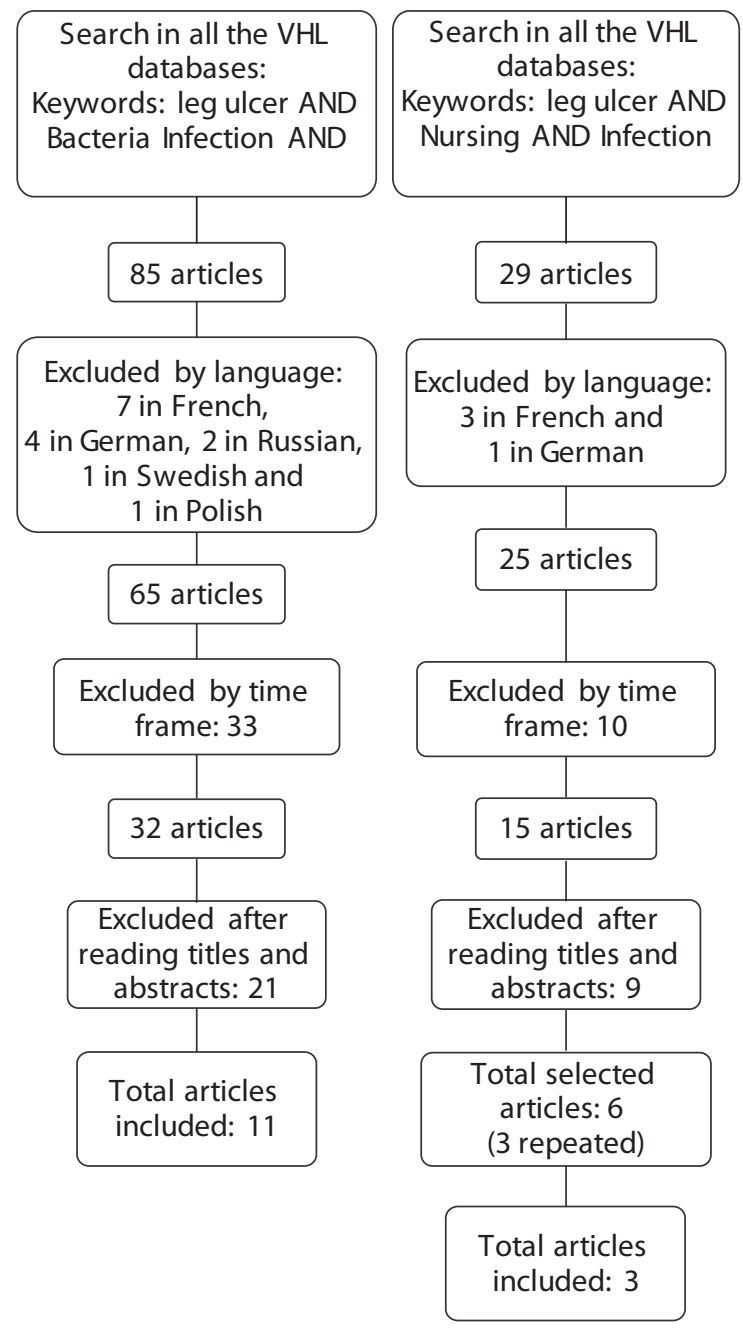

Fourteen studies were included in the analysis. Figures 2 and 3 were built after the analytical reading of the selected studies.

The characteristics year, country, study design, interventions, outcomes, and ratings were highlighted according to STROBE or CONSORT, in accordance with the selected type of study.

It is possible to observe homogeneity in the number of selected studies regarding the methods, as $50 \%$ (seven studies) were observational studies and 50\% (seven) were experimental studies.

\section{DISCUSSION}

The results of this research were organized in two categories for discussion: "Main microorganisms found in tissular lesions" and "Main products used in tissular lesions with signs of infection."

Category 1: Main microorganisms found in tissular lesions

A study conducted in Goiania in $2010^{(1)}$ was significantly relevant to the construction of this category. The research analyzed 60 lesions of ambulatory patients, among which, 75\% were infected.

These research findings confirm other studies that highlight anaerobes, gram-negative bacilli and gram-positive cocci as significant microorganisms in relation to the colonization, contamination or infection of tissular lesions, and the most common ones are the Enterobacter, Klebsiella pneumoniae, Pseudomonas, Acinetobacter and Staphylococcus ${ }^{(4.22)}$. Among the isolated Gram-positive bacteria, $65 \%$ were Staphylococcus aureus. However, among gramnegative bacteria, $23 \%$ of the isolated ones were Pseudomonas aeruginosa. Similar results were observed in the United Kingdom and the United States ${ }^{(11)}$.

The collection of biological material was made from the viable granulation tissue using sterilized alginate swab, according to Levine's technique and this occurred after the cleaning of the lesion, which was made with the use of a bottle of physiologic serum at $0.9 \%(125 \mathrm{ml})$ through the piercing with a $40 \times 12$ needle. This author points out that one should moisten the tip of the swab with physiological serum at $0.9 \%$ and then press it, turning it by $1 \mathrm{~cm}^{2}$ on its axis for 5 seconds in the wound area, so that there is an expression of tissue fluid ${ }^{(1)}$. 
Figure 2 - Observational studies on the main microorganisms found in contaminated tissular lesions. Niteroi, 2014

\begin{tabular}{|c|c|c|c|c|c|}
\hline Code & $\begin{array}{l}\text { Year / } \\
\text { Country }\end{array}$ & Design & $\begin{array}{l}\text { Collection of bio- } \\
\text { logical material }\end{array}$ & Outcomes & $\begin{array}{l}\text { STRO- } \\
\text { BE }\end{array}$ \\
\hline 1 & 2010/Brazil & Transverse & Swab & $\begin{array}{l}\text { Most prevalent microorganisms: S. aureus } \\
\text { and P. aeruginosa. } \\
\text { S. aureus was sensitive to most antibiotics } \\
\text { tested }\end{array}$ & A \\
\hline 9 & $\begin{array}{l}\text { 2012/Den- } \\
\text { mark }\end{array}$ & Transverse & $\begin{array}{l}\text { Swab, biopsy, pad } \\
\text { paper filter }\end{array}$ & $\begin{array}{l}\text { There was no significant difference in bacte- } \\
\text { rial isolates in each of the techniques }\end{array}$ & A \\
\hline 10 & 2008/Brazil & Case report & swab & $\begin{array}{l}\text { Corynebacterium was isolated } \\
\text { pseudodiphtheriticum }\end{array}$ & $\mathrm{B}$ \\
\hline 11 & $\begin{array}{l}\text { 2009/Uni- } \\
\text { ted States }\end{array}$ & $\begin{array}{l}\text { Prospective pilot } \\
\text { study }\end{array}$ & $\begin{array}{l}\text { Swab, PVA discs and } \\
\text { biopsy }\end{array}$ & $\begin{array}{l}\text { The swab was the technique that has isola- } \\
\text { ted a greater quantity of microorganisms. } \\
\text { Main microorganisms isolated: S. aureus and } \\
\text { P. aeruginosa }\end{array}$ & A \\
\hline 12 & $\begin{array}{l}\text { 2008/ } \\
\text { United } \\
\text { States }\end{array}$ & $\begin{array}{l}\text { Retrospective } \\
\text { descriptive study } \\
\text { (medical record } \\
\text { analysis) }\end{array}$ & $\begin{array}{l}\text { Antibiofilm agents } \\
\text { (Lactoferrin and } \\
\text { Xylitol) }\end{array}$ & $\begin{array}{l}\text { A significant improvement of the wound } \\
\text { healing rate }\end{array}$ & $\mathrm{A}$ \\
\hline 13 & $\begin{array}{l}2007 \\
\text { United } \\
\text { States }\end{array}$ & Literature Review & Analysis of literature & $\begin{array}{l}\text { It was observed that there are microorganis- } \\
\text { ms that are resistant to silver, isolatd lesions }\end{array}$ & B \\
\hline 14 & $\begin{array}{l}2009 \\
\text { India }\end{array}$ & Cohort & swab & $\begin{array}{l}\text { Most frequently encountered organisms: } P \text {. } \\
\text { aeruginosa, E. coli and S. aureus. } \\
\text { Most microorganisms were resistant to the } \\
\text { antibiotics tested }\end{array}$ & A \\
\hline
\end{tabular}

Figure 3 - Experimental studies on the key products used in contaminated tissular lesions. Niteroi, 2014

\begin{tabular}{|c|c|c|c|c|c|}
\hline $\begin{array}{l}\text { Refe- } \\
\text { rence } \\
\text { num- } \\
\text { ber }\end{array}$ & $\begin{array}{l}\text { Year/ } \\
\text { country }\end{array}$ & $\begin{array}{l}\text { Study(ies) } \\
\text { design }\end{array}$ & Interventions & Outcomes & $\begin{array}{l}\text { CON- } \\
\text { SORT }\end{array}$ \\
\hline 15 & $\begin{array}{c}2012 / \\
\text { Canada }\end{array}$ & $\begin{array}{l}\text { Randomized con- } \\
\text { trolled clinical trial }\end{array}$ & Silver alginate & $\begin{array}{l}\text { Silver alginate was effective to reduce infection } \\
\text { scores and area of infected lesions }\end{array}$ & A \\
\hline 16 & $\begin{array}{l}\text { 2007/ } \\
\text { Nether- } \\
\text { lands }\end{array}$ & Pilot study & Dermacine & $\begin{array}{l}\text { The use of Demacine in chronic lesions is not } \\
\text { advisable }\end{array}$ & \\
\hline 17 & $\begin{array}{l}\text { 2005/ } \\
\text { France }\end{array}$ & $\begin{array}{l}\text { Comparative, } \\
\text { randomized and } \\
\text { multicenter study }\end{array}$ & Silver Alginate & $\begin{array}{l}\text { Favorable clinical influence in lesions at high } \\
\text { risk of infection; few lesions developed clinical } \\
\text { infection }\end{array}$ & $A$ \\
\hline 18 & $\begin{array}{c}2012 / \\
\text { USA }\end{array}$ & Phase II Trial & $\begin{array}{l}\text { Antimicrobial pho- } \\
\text { todynamic therapy }\end{array}$ & $\begin{array}{l}\text { Significant reduction in bacterial load imme- } \\
\text { diately after treatment }\end{array}$ & A \\
\hline 19 & $\begin{array}{c}\text { 2005/ } \\
\text { Canada }\end{array}$ & $\begin{array}{l}\text { Intervention } \\
\text { research }\end{array}$ & Ultraviolet light C & Significant reduction of predominant bacteria & A \\
\hline 20 & $\begin{array}{c}\text { 2013/ } \\
\text { USA }\end{array}$ & Case reports & $\begin{array}{l}\text { Silver sulfadiazine } \\
\text { (SSD Urgotul) }\end{array}$ & $\begin{array}{l}\text { Effectiveness against a broad spectrum of } \\
\text { microorganisms }\end{array}$ & B \\
\hline 21 & $\begin{array}{l}\text { 2012/ } \\
\text { France }\end{array}$ & $\begin{array}{l}\text { Randomized clini- } \\
\text { cal trial }\end{array}$ & $\begin{array}{l}\text { Silver lipocolóide } \\
\text { dressing in lesions } \\
\text { with signs of infec- } \\
\text { tion }\end{array}$ & $\begin{array}{l}\text { Significant decrease in the lesion area with } \\
\text { signs of inflammation and high bacterial load }\end{array}$ & A \\
\hline
\end{tabular}


On the other hand, there are other studies that also highlight other microorganisms as significantly frequent in wounds, such as negative coagulase Staphylococcus, Escherichia coli, Bacteroides spp., Peptostreptococcus, Enterococcus spp. and Streptococcus pyogenes ${ }^{(1,2,23)}$.

In addition, the susceptibility of the microorganisms found in the lesions to the antimicrobial agents was evaluated in this study ${ }^{(1)}$. It is worth noting that the results of antimicrobial susceptibility testing in terms of the microorganisms found in the lesions indicated strains of S. aureus which presented sensitivity of $70 \%$ and $80 \%$ to oxacillin, tetracycline, lincomycin and cephalexin as well as strains with sensitivity above $80 \%$ to pefloxacine and vancomycin. With regard to $P$. aeruginosa, we identified $100 \%$ susceptibility to gentamicin, in addition to other positive rates of susceptibility to cefotaxime, aztreonam, ciprofloxacin and amikacin. However, there was an $86 \%$ resistance to ampicillin associated with clavulanic acid and $93 \%$ to cephalexin ${ }^{(1)}$.

Thus, it is noticed that there are several microorganisms that affect lesions and this fact increases the importance of research initiatives involving reviews on these microorganisms. Thus, the collection and laboratory culture of bacterial cells obtained from biological material that was removed from tissular lesions, when there is a suspicion of infection, contributes to the specific and direct care of patients with infected wounds.

The microbiota of chronic wounds reflected in large part, the antibiotics that were administered to patients before. Thus, the importance of identifying this specific microorganism in the lesion to start the appropriate topical and/or systemic treatment is unquestionable ${ }^{(23)}$.

The liberal use of topical and systemic antibiotics can promote the appearance of multidrug resistant and potentially lethal bacteria.
Therefore, the prescription of antibiotic treatment should be made, whenever possible, from the identification of the pathogen of each lesion, as well as its sensitivity to the chosen treatment.

Thus, the choice of systemic or topical antimicrobial should be based on these criteria: clinical and epidemiological concerning the possible pathogenesis and cause of the infection; microbiological, regarding the possible microbiota involved, especially the methods of collection of biological material from the lesion, tissue or mucosa infected for laboratory testing; and pharmacological, with respect to knowledge about the indicated drug ${ }^{(1)}$.

Thus, it can be said that the identification of microorganisms present in the lesion becomes essential to avoid both multidrug-resistant strains and major complications for patients. The main one involves the risk of spread of the local infection into the bloodstream, which could cause death by sepsis.

\section{Category 2: The Main products used in tissular lesions with signs of infection}

The infected lesions are characterized by a significant delay in the healing process, requiring the application of products that interrupt or end up with bacterial growth ${ }^{(24)}$. In addition, it is noteworthy that many of these bactericidal and/ or bacteriostatic products can be cytotoxic to healthy human cells, affecting the entire tissue repair process. It is therefore important to evaluate the effectiveness of the product in relation to the reduction of bacterial load ${ }^{(25)}$, since the wounds are a major gateway to infections ${ }^{(26)}$. Thus, based on the clinical signs of infection and after proof of the presence of bacteria, properly choosing the topical or systemic therapy to be applied becomes important.

The technologies used and highlighted in the studies were silver alginate powder, Derma- 
cine $^{\circledR}$, Silver Alginate, photodynamic antimicrobial therapy, ultraviolet light C, Urgotul SSD ${ }^{\circledR}$ and silver lipo colloidal dressing.

The study on the dressing in silver alginate powder, showing signs of critical colonization in the management of chronic wounds, was a randomized controlled clinical trial with 34 patients. We have identified a statistically significant decrease in the infection of the lesions when comparing the beginning with the end of the treatment in the experimental group. $\mathrm{Pa}$ tients randomized to the Group silver achieved a reduction of the surface wounds greater than those who were randomly assigned to use the foam dressing (control). Thus, it can be said that silver alginate powder is an effective option for treating wounds with increased bacterial load ${ }^{(15)}$.

The dermacine formulation is based on a solution of super-oxidized, purified and neutral $\mathrm{pH}$ water, containing reactive oxygen species in a stable formulation. It is capable of destroying bacteria, viruses and spores at significant rates in vitro and promoting the healing of diabetic foot ulcers and burns. In this pilot study we included ten patients with chronic lesions in the lower limbs, in order to describe the experience of using dermacine in these lesions and the outcomes were the elimination of bacteria and the assessment of the adverse effects. Four patients did not maintain treatment with dermacine due to significant reports of pain and there was only one change in microbiology ulcer. The small sample evaluated indicates the need for further studies with a larger number of patients to elucidate the effects of dermacine in the pain and in the reduction of the microbial load, which, for instance, is not recommended for the treatment of chronic lesions ${ }^{(16)}$.

Aiming to evaluate the clinical impact in terms of the use of an Alginate and silver based cover in reducing the risk of local infection in chronic colonized lesions of 48 patients, we con- ducted a randomized clinical trial with Alginate and silver (experiment) and calcium alginate (control). We found that the use of Alginate with silver at wounds presenting high risk of infection can have a clinically favorable influence in terms of the prognosis of the lesions to promote debridement, control bacterial growth and improve healing rates, thus preventing the need for systemic antibioticotherapy ${ }^{(17)}$.

The antimicrobial photodynamic therapy (APT), in turn, has the potential to accelerate wound healing and prevent clinical infection, particularly in patients with chronic leg ulcers. This is an effective alternative for the treatment of localized microbial infections and it occurs through the application of a gel in the lesion, whose formulation is still being tested, so no details were reported in the study. Then the wound is occluded with APP 680 Lux light rays for 1000 seconds through a photosensitizer ${ }^{(18)}$.

While any photosensitizing works to kill gram-positive bacteria, we consider phenothiazine as a more suitable option to remove a broad spectrum of gram-negative microorganisms, which are more difficult to eradicate. The photoinactivation of various microorganisms has been demonstrated, including Escherichia coli, Staphylococcus aureus, methicillin-resistant Staphylococcus aureus, Pseudomonas aeruginosa and Candida albicans ${ }^{(18)}$.

The great benefit generated by the photodynamic therapy is the significant reduction of the bacterial load in the lesions, in addition to effects on stimulation of growth factors and immune response. Thus, it is considered a safe treatment and it was well tolerated by patients with leg ulcers or diabetic foot lesions, without reports of pain or other complications. As a limitating factor, it should be noted that this is not a strategy for the treatment of systemic infections and it needs to be associated with drug therapy ${ }^{(18)}$. 
Ultraviolet light (UVL) occupies the electromagnetic spectrum between $\mathrm{X}$-rays and visible light. The UVL wavelengths are divided into three bands: UVA (320 $\mathrm{nm}$ to $400 \mathrm{~nm}$ ), UVB (290 $\mathrm{nm}$ to $320 \mathrm{~nm}$ ) and UVC (200 nm to $290 \mathrm{~nm})$. UVA and UBV bands have minimum bactericidal properties. They are used mainly for treating dermatological conditions such as psoriasis and dermatitis. UVC is also used in wound healing ${ }^{(19)}$.

It has been identified that ultraviolet $C$ light is capable of killing bacteria in vitro and in vivo, including antibiotic-resistant bacteria such as methicillin-resistant Staphylococcus aureus (MRSA), without adversely affecting the healthy tissue in the lesion. In this sense, in order to determine whether the UVC is effective on bacteria, semiquantitative results obtained by swabs that were collected immediately before and after treatment by means of UVC were compared, without other products applied to the lesion ${ }^{(19)}$.

We observed a statistically significant reduction of bacteria prevalent in lesions of 18 patients included in the study, and there were significant decreases in MRSA, S. aureus and other forms of bacteria. Other side effects such as blisters or burns resulting from exposure to UVC in 180 seconds period were not observed ${ }^{(19)}$.

Sulfadiazine is an antibiotic and acts synergistically with silver for increasing the capacity of elimination of bacteria in the lesions. This is because silver is an inert metal which does not react to human tissue in its nonionized form. When it comes into contact with fluids such as exudate from a wound, silver ions $(\mathrm{Ag}+)$ are released. It is believed that these ions attach themselves to the bacterial cell surface proteins, inhibiting the cell respiration, which determines the death of these cells and reduces the amount of microorganisms present in the lesion ${ }^{(20)}$.

Urgotul SSD ${ }^{\circledR}$ is a non-adherent antibacterial dressing, composed of a matrix impregnated with particulate carboxymethylcellulose, petro- leum jelly and silver sulfadiazine. It is effective against a broad spectrum of microorganisms, especially Pseudomonas aeruginosa and Escherichia coli. Studying cases of different types of wounds, such as venous ulcers and surgically infected lesions, it was observed that Urgotul $\mathrm{SSD}^{\circledR}$ is clinically effective in reducing the bacterial load and the promotion of wound healing. We can also emphasize the reduction of pain and trauma due to the non-adhesive characteristics of the product ${ }^{(20)}$.

With this, one can see that there are many microorganisms found in the lesions and there are many products used in these lesions, especially those made with silver base in the treatment of wounds with signs of infection. The study highlights the importance of identifying the microorganism in a specific manner to guide an adequate specific treatment aimed, primarily, to promote the health of patients, avoiding infections.

\section{CONCLUSION}

Articles found by the Integrative search underscore the importance of the clinical evaluation of ulcers, especially with regard to the main characteristic signs of infected lesions.

The importance of identifying the species of common microorganisms becomes relevant to guide the professional facing an injury, that is, the microorganism that he may suspect for further laboratory research. Studies point to Pseudomonas aeruginosa and Staphylococcus aureus as the most prevalent in injury. We may also highlight Enterobacter, Klebsiella pneumoniae and Acinetobacter as species of microorganisms commonly found in lesions.

As the main products used on infected skin lesions, studies highlighted silver alginate, ultraviolet light, and silver sulfadiazine as effective products 
on the antimicrobial load. The use of Dermacine is not indicated for wounds with clinical signs of infection, as it has produced significant increase of pain in patients treated therewith.

Many studies have emphasized the identification of microorganisms in lesions. However, only three of them related to use of a product to its action in reducing the presence of certain micro-organism by means of more specific laboratory tests. Therefore we suggest conducting researches related to infection and skin lesions directed to laboratory confirmation of the presence of bacteria and subsequent reduction of this microbial load by means of laboratory tests, not only through clinical signs.

Thus, it can be said that the identification of microorganisms through accurate laboratory tests and determination of antimicrobial susceptibility are important to guide an appropriate treatment, contributing to the rational use of antimicrobials.

\section{REFERENCES}

1. Martins MA, Tipple AFV, Reis C, Santiago SB, Bachion MM. Úlcera crônica de perna de pacientes em tratamento ambulatorial: análise microbiológica e de suscetibilidade antimicrobiana. Cienc Cuid Saude (Online) [Internet]. 2010 [Cited 2014 Oct 3] 9(3):464-70. Available from: http://periodicos. uem.br/ojs/index.php/CiencCuidSaude/ article/view/8178/6635. [included in the review]

2. Zaho G, Hochwalt PC, Usui ML, et al. Delayed Wound Healing in Diabetic (db/db) Mice with Pseudomonas aeruginosa Biofilm Challenge - A Model for the Study of Chronic Wounds. Wound Repair Regen. (Online) [Internet] 2010 [Cited 2014 Oct 3] 18(5):467-77. Available from: http:// onlinelibrary.wiley.com/doi/10.1111/j.1524475X.2010.00608.x/pdf

3. Silva RCL, Figueiredo NBA, Meireles IB, et al. Feridas, fundamentos e atualizações em enfermagem. 3. ed. São Paulo: Yendis editora; 2011.
4. Tuttle MS, Mostow E, Mukherjee P, et al. Characterization of Bacterial Communities in Venous Insufficiency Wounds by Use of Conventional Culture and Molecular Diagnostic Methods. Journal of Clinical Microbiology. (Online) [Internet] 2011 [Cited 2014 Oct 3] 49(11):3812-19. Available from: http://jcm.asm.org/content/49/11/3812.long

5. Turhan $V$ et al. Increasing incidence of Gram-negative organisms in bacterial agents isolated from diabetic foot ulcers. J Infect Dev Ctries. (Online) [Internet] 2013 [Cited 2014 Oct 3] 7(10):707-712. Available from: file:///C:/Users/ Win/Downloads/2967-24527-1-PB.pdf

6. Rhoads DD, Cox SB, Rees EJ, Sun Y, Wolcott RD. Clinical identification of bacteria in human chronic wound infections: culturing vs. $16 \mathrm{~S}$ ribosomal DNA sequencing. BMC Infectious Diseases. (Online) [Internet] 2012 [Cited 2014 Oct 3] 12(321):1-8. Available from: http://www.biomedcentral.com/ content/pdf/1471-2334-12-321.pdf

7. Von Elm E, Altman DG, Egger M, Pocock SJ, Gøtzsche PC, Vandenbroucke JP; et al. The Strengthening the Reporting of Observational Studies in Epidemiology (STROBE) statement: guidelines for reporting observational studies. J Clin Epidemiol. (Online) [Internet] 2008 [Cited 2014 Oct 3] 61(4):344-9. Available from: http://www.ncbi. nlm.nih.gov/pmc/articles/PMC2034723/pdf/ bmj-335-7624-ac-00806.pdf

8. Taminato $M$, Fram $D$, Torloni MR, Belasco AGS, Saconato $\mathrm{H}$, Barbosa DA. Rastreamento de Streptococcus do grupo $B$ em gestantes: revisão integrativa e metanálise. Revista Latino Americana de Enfermagem. (Online) [Internet] 2011 [Cited 2014 Oct 3] 19(6):[9 telas]. Available from: http:// www.scielo.br/pdf/rlae/v19n6/26.pdf

9. Gjødsbøl K, Skindersoe ME, Christensen JJ, Karlsmark $T$, Jørgensen B, Jensen AM, Klein BM, Sonnested MK, Krogfelt KA. No need for biopsies: comparison of three sample techniques for wound microbiota determination. Int Wound J. 2012 [Cited 2014 Oct 8] 9(3): 295-302. [included in the review]

10. Cantarelli VV, Brodt TCZ, Secchi C, Inamine $E$, Pereira FS. Cutaneous infection caused by Corynebacterium pseudodiphtheriticum. A microbiological report. Rev. Inst. Med. trop. S. Paulo. (Online) [Internet] 2008 [Cited 2014 Oct 
8] 50(1):51-52. Available from: http://www.scielo. $\mathrm{br} / \mathrm{pdf} / \mathrm{rimtsp} / \mathrm{v} 50 \mathrm{n} 1 / \mathrm{a} 11 \mathrm{v} 50 \mathrm{n} 1 . \mathrm{pdf}$ [included in the review]

11. Cooper RA, Ameen H, Price P, McCulloch DA, Harding KG. A clinical investigation into the microbiological status of 'locally infected'leg ulcers. Int Wound J. 2009 [Cited 2014 Oct 8] 6(6): 453-62. [included in the review]

12. Wolcott RD, Rhoads DD. A study of biofilm-based wound management in subjects with critical limb ichaemia. Journal of wound care. 2008 [Cited 2014 Oct 8] 17(4): 145-155. [included in the review]

13. Landsdown $A B$, Williams $A$. Bacterial resistance to silver in wound care and medical devices. J Wound Care. 2007 [Cited 2014 Oct 8] 16(1): 15-9. [included in the review]

14. Basu S, Ramchuran Panray T, Bali Singh T, Gulati AK, Shukla VK. A prospective, descriptive study to identify the microbiological profile of chronic wounds in outpatients. Ostomy Wound Manage. (Online) [Internet] 2009 [Cited 2014 Oct 8] 55(1): 14-20. Available from: http://www.o-wm.com/ content/a-prospective-descriptive-study-identify-microbiological-profile-chronic-wounds-outpatients. [included in the review]

15. Woo KY, Coutts PM, Sibbald RG. A randomized controlled trial to evaluate an antimicrobial dressing with silver alginate powder for the management of chronic wounds exhibiting signs of critical colonization. Adv Skin Wound Care. 2012 [Cited 2014 Oct 8] 25(11): 503-8. [included in the review]

16. Steenvoorde P, Doorn LPV, Jacobi CE, Oskam J. An Unnexpected effect of Dermacyn on infected leg ulcer. Journal of wound care. 2007 [Cited 2014 Oct 15] 16(2): 60-61. [included in the review]

17. Meaume S, Vallet D. Evalluation of a silver-releasing hydroalginate dressing in chronic wounds with signals of local infection. Journal of wound care. 2005 [Cited 2014 Oct 15] 14(9): 411-419. [included in the review]

18. Brown S. Clinical antimicrobial photodynamic therapy: phase Il studies in chronic wounds. J Natl Compr Canc Netw. (Online) [Internet] 2012 [Cited 2014 Oct 15] 10 Suppl 2: S80-3. Available from: http://www.jnccn.org/content/10/Suppl_2/S-80. full.pdf+html[included in the review]
19. Thai TP, Keast DH, Campbell KE, Woodbury MG, Houghton PE. Effect of ultraviolet light $C$ on bacterial colonization in chronic wounds. Ostomy Wound Manage. (Online) [Internet] 2005 [Cited 2014 Oct 8] 51(10): 32-45. Available from: http:// www.o-wm.com/content/effect-ultraviolet-light-c-bacterial-colonization-chronic-wounds [included in the review]

20. Downe A. Use of Urgotul SSD to reduce bacteria and promote healing in chronic wounds. $\mathrm{Br} J$ Community Nurs. 2013 [Cited 2014 Oct 8] Suppl: S32, S34-8. [included in the review]

21. Lazareth I, Meaume S, Sigal-Grinberg ML, Combemale P, Le Guyadec T, Zagnoli A. Efficacy of a silver lipidocolloid dressing on heavily colonised wounds: a republished RCT. J Wound Care. 2012 [Cited 2014 Oct 8] 21(2): 96-102. [included in the review]

22. Nasir NM, Halim AS, Singh KB, Dorai AA, Haneef $M M$. Antibacterial properties of tualang honey and its effect in burn wound management: a comparative study. BMC Complementary and Alternative Medicin. (Online) [Internet] 2010 [Cited 2014 Oct 8] 10(31). Available from: http://www. biomedcentral.com/1472-6882/10/31

23. Han A, Zenilman JM, Melendez JH, et al. The importance of a multi-faceted approach to characterizing the microbial flora of chronic wounds. Wound Repair Regen. (Online) [Internet] 2011 [Cited 2014 Oct 8] 19(5):532-541. Available from: http://onlinelibrary.wiley.com/doi/10.1111/ j.1524-475X.2011.00720.x/p df

24. Hirsch T, Spielmann M, Zuhaili B, et al. Enhanced susceptibility to infections in a diabetic wound healing model. BMC Surgery. (Online) [Internet] 2008 [Cited 2014 Oct 8] 8(5). Available from: http://www.ncbi. nlm.nih.gov/pmc/articles/ PMC2276479/pdf/1471-2482-8-5.pdf

25. Burkatovskaya $M$, Caetano AP, Demivoda-rice TN, Tegos GP, Hamblin MR. Effect of chitosan acetate bandage on wound healing in infected and noninfected wounds in mice. Wound Repair Regen. (Online) [Internet] 2008 [Cited 2014 Oct 8] 16(3). Available from: http://onlinelibrary.wiley. com/doi/10.1111/j.1524-475X.2008.00382.x/pdf

26. Dantas ALM, Ferreira PC, Valença CN, Diniz KD, Nunes JP, Germano RM. Complications of pressure ulcers in severely ill patients: a descriptive- 
-exploratory study. Online braz j nurs [Internet]. 2013 June [cited 2014 Nov 27] 12(2). Available from: http://www.objnursing.uff.br/index.php/ nursing/article/view/3794 . doi: http://dx.doi. org/10.5935/1676-4285.20133794

Participation of the authors in the research:

Fernanda Soares Pessanha and Bruna Maiara Ferreira Barreto: collection, analysis and interpretation of data Beatriz Guitton Renaud Baptista de Oliveira, Miriam Marinho Chrizostimo, Deise Ferreira de Souza and Thiago Thomaz Mafort: design and review of the manuscript

All authors participated in the phases of this publication in one or more of the following steps, in According to the recommendations of the International Committee of Medical Journal Editors (ICMJE, 2013): (a) substantial involvement in the planning or preparation of the manuscript or in the collection, analysis or interpretation of data; (b) preparation of the manuscript or conducting critical revision of intellectual content; (c) approval of the versión submitted of this manuscript. All authors declare for the appropriate purposes that the responsibilities related to all aspects of the manuscript submitted to OBJN are yours. They ensure that issues related to the accuracy or integrity of any part of the article were properly investigated and resolved. Therefore, they exempt the OBJN of any participation whatsoever in any imbroglios concerning the content under consideration. All authors declare that they have no conflict of interest of financial or personal nature concerning this manuscript which may influence the writing and/or interpretation of the findings. This statement has been digitally signed by all authors as recommended by the ICMJE, whose model is available in http://www. objnursing.uff.br/normas/DUDE_eng_13-06-2013.pdf
Received: $11 / 29 / / 2014$

Revised: $12 / 17 / 2014$

Approved: $12 / 17 / 2014$ 